\title{
Inactivation of Adenovirus Types 2, 5, and 41 in Drinking Water by UV Light, Free Chlorine, and Monochloramine
}

\author{
Carole S. Baxter ${ }^{1}$, Ron Hofmann ${ }^{2}$, Michael R. Templeton ${ }^{3}$, Martha Brown ${ }^{4}$, \\ and Robert C. Andrews 5
}

\begin{abstract}
A bench-scale study was conducted to determine the inactivation of adenovirus types 2,5 , and 41 by ultraviolet (UV) light, chlorine, and monochloramine. The motivation for this study was to determine whether UV disinfection followed by chlorine or monochloramine for a very short contact time (e.g. a minute) could satisfy regulatory requirements for 4-log virus inactivation. In order to overcome the difficulty Ad 41 presents for enumeration of the virus in cell culture, a technique was used that combined immunofluorescent staining of viral antigen with traditional scoring of cytopathic effect (CPE). A UV dose of $40 \mathrm{~mJ} / \mathrm{cm}^{2}$ (millijoules per square centimetre) (applied using a collimated beam apparatus) achieved approximately 1-log inactivation of adenovirus (Ad) types 2, 5 and 41, confirming previous research. Ad 41 was found to be more UV-resistant to UV light than Ad 2 or Ad 5 at UV doses $>70 \mathrm{~mJ} / \mathrm{cm}^{2}$ to a statistically significant degree (95\% confidence); however, at lower UV doses there were no statistically significant differences. Experiments with $\mathrm{Ad} 5$ and $\mathrm{Ad} 41$ at $5{ }^{\circ} \mathrm{C}$ and $\mathrm{pH} 8.5$ showed that chlorine was very effective against Ad 5 and Ad 41, with a CT (product of disinfectant concentration and contact time) of $0.22 \mathrm{mg} \cdot \mathrm{min} / \mathrm{L}$ providing 4-log inactivation. Monochloramine was less effective against these adenoviruses, with a $\mathrm{CT}$ of $350 \mathrm{mg} \cdot \mathrm{min} / \mathrm{L}$ required to achieve $2.5-\log$ inactivation of $\mathrm{Ad} 5$ and 41 at $5^{\circ} \mathrm{C}$ and $\mathrm{pH} 8.5$.
\end{abstract}

CE Database subject headings: potable water, disinfection, ultraviolet radiation, chlorine, pathogens, water treatment, waterborne diseases, chloramine 
${ }^{1}$ Research microbiologist, Dept. of Civil Engineering, University of Toronto, 35 St. George Street, Toronto, Ontario, Canada M5S 1A4. E-mail: carole.baxter@utoronto.ca

2 Assistant Professor, Dept. of Civil Engineering, University of Toronto, 35 St. George

Street, Toronto, Ontario, Canada M5S 1A4. E-mail: hofmann@ecf.utoronto.ca

${ }^{3}$ Ph.D. Candidate, Dept. of Civil Engineering, University of Toronto, 35 St. George Street, Toronto, Ontario, Canada M5S 1A4. E-mail: michael.templeton@utoronto.ca

${ }^{4}$ Associate Professor, Dept. of Medical Genetics and Microbiology, University of Toronto, 1 King's College Circle, Toronto, Ontario, Canada M5S 1A8.

E-mail: martha.brown@utoronto.ca

${ }^{5}$ Professor, Dept. of Civil Engineering, University of Toronto, 35 St. George Street, Toronto, Ontario, Canada M5S 1A4. E-mail: andrews@ecf.utoronto.ca 


\section{INTRODUCTION}

Drinking water regulations in many North American jurisdictions stipulate that treatment of surface water or groundwater under the direct influence of surface water (GUDI waters) must achieve a minimum 4-log (99.99\%) reduction of viruses (USEPA 1989, Ontario Ministry of the Environment 2003). This reduction can be achieved by a combination of physical removal (via coagulation, flocculation, sedimentation, and/or filtration) and by inactivation using disinfectants. Traditionally, free chlorine or chloramines have been used for virus inactivation. In many cases, such as in the disinfection of well water, disinfection may be the only barrier to viral pathogens.

In recent years, ultraviolet (UV) disinfection has become popular in drinking water treatment due to its ability to inactivate chlorine-resistant pathogens (e.g. Cryptosporidium, Giardia) at relatively low, economical doses, and due to the absence of any known harmful disinfection by-products. While most viruses are more difficult to inactivate with UV light than bacteria or protozoa, a UV dose (or 'fluence') of $40 \mathrm{~mJ} / \mathrm{cm}^{2}$ applied by collimated beam exposures at bench-scale has been shown to successfully achieve 4-log inactivation of many waterborne viral pathogens including echovirus, coxsackievirus, calicivirus, and poliovirus (Thurston-Enriquez et al. 2003; Gerba et al. 2002; Shin et al. 2001; Meng and Gerba 1996). However, a particularly UV-resistant viral pathogen, adenovirus, has been reported by the same authors to be more than four times as resistant to UV light than these other viruses.

The adenoviruses are non-enveloped particles that contain a double-stranded DNA genome packaged within an icosahedral capsid, or protein coat. Fifty-one serotypes of human adenoviruses have been identified and classified within six species (labelled A through F) based on DNA-relatedness (van Regenmortel et al. 2000). Adenovirus types from species B 
(Ad 3) and species E (Ad 4) have been identified as causative agents of recreational waterborne outbreaks of conjunctivitis and pharyngoconjunctival fever (McMillan et al. 1992, Martone et al. 1980, D’Angelo et al. 1979). The species F adenoviruses, enteric types 40 and 41, have been identified as causative agents of gastroenteritis (Uhnoo et al. 1984, Horwitz 2001). Ad 2 and Ad 5, species C adenoviruses, are less frequently associated with gastroenteritis (Brown 1990) but have been well-characterized and, unlike the fastidious enterics, grow well in cell culture. Species $\mathrm{C}$ adenoviruses are primarily respiratory pathogens that can also cause conjunctivitis and that have been associated with serious widespread disease in immuno-compromised patients.

Most relevant to the study of drinking water are the enteric adenoviruses. Transmission of these agents in drinking water has been documented (Kukkula et al. 1997). Infectious adenoviruses have been detected in surface waters, wastewater, and UV-irradiated wastewater (Van Heerden et al. 2003, Thompson et al. 2003, Chapron et al. 2000) including samples in which the number of coliforms was below the detectable limit, thus raising the issue of suitability of traditional bacterial indicators for water quality monitoring (Van Heerden et al. 2003, Thompson et al. 2003). The range of environments in which adenoviruses have been detected is not surprising given their observed ability to persist and remain infectious in water.

Due to the relative UV-resistance of adenoviruses when compared to other viruses, the recent United States Environmental Protection Agency (USEPA) UV Disinfection Guidance Manual that accompanied the Long Term 2 Enhanced Surface Water Treatment Rule developed the UV dose requirements for the log inactivation of 'viruses' based on the UV inactivation kinetics of adenovirus (USEPA 2006). For example, obtaining credit for the 
4-log inactivation of viruses by UV disinfection requires application of a UV reduction equivalent dose (RED) (proven by biodosimetry validation) of $186 \mathrm{~mJ} / \mathrm{cm}^{2}$ (USEPA 2006). This is much higher than the typical previously recommended UV RED of $40 \mathrm{~mJ} / \mathrm{cm}^{2}$ (NWRI-AWWA 2003, ONORM 2001, DVGW 1997) and thus would require higher capital and operating costs.

While achieving 4-log reduction of adenovirus may be difficult using UV alone in some cases, studies have found that adenovirus, like most enteric viruses, are quite susceptible to inactivation by chlorine (Thurston-Enriquez et al. 2003, Shin et al. 2002). It is therefore practical in a treatment train employing UV light as a primary disinfectant to use chlorine as a secondary disinfectant. This strategy is easily applied in large water treatment plants where disinfectant contact time is often achieved in a clearwell. There are, however, many GUDI well locations where UV light is applied for primary disinfection in the absence of physical treatment or basins to provide a chemical disinfectant contact time. In these cases, chemical disinfectant is often added immediately prior to entry into the distribution system, although the available disinfection contact time may be limited to only seconds prior to the water reaching the first consumer (Fig. 1). In many such situations, it is not possible to build storage to provide chemical disinfectant contact time due to space constraints, such as when the well house is located within a built-up community. There is therefore a need to know if very small $\mathrm{CT}$ values using chlorine or monochloramine, consistent with travel through the distribution system to a nearby consumer, are sufficient to meet the regulatory requirements of 4-log (adeno)virus inactivation. While the kinetics obtained at larger CT values from previous studies (e.g. Shin et al. 2002) can be extrapolated to suggest that chlorine may be effective at low CT values, the importance of this issue to many water supplies requires that 
experiments recreate the low $\mathrm{CT}$ conditions experienced in the field to confirm adequate adenovirus control. This will guard against the possibility that extrapolated linear inactivation kinetics (e.g. Chick-Watson) do not apply in the low CT region for adenovirus. ThurstonEnriquez et al. (2003) showed that a 4-log inactivation of Ad 40 can be achieved by a chlorine $\mathrm{CT}$ of $0.24 \mathrm{mg} \cdot \mathrm{min} / \mathrm{L}$ for $\mathrm{pH} 8$ and $5{ }^{\circ} \mathrm{C}$ in demand-free buffer. It is unknown whether low CT values for monochloramine would be suitable under similar conditions.

This study also explored potential differences in the UV inactivation kinetics of different types of adenovirus, specifically 2, 5, and 41. Much of the regulatory literature concerning adenovirus is based on inactivation tests using types 2 and 5 as surrogates to type 41, which is the type of concern for drinking water exposure but is far more difficult to handle in the lab.

The main objectives of this study were: (1) to determine the inactivation kinetics of adenovirus type 41 in the presence of chlorine and monochloramine under anticipated challenging conditions $\left(\mathrm{pH} 8.5,5^{\circ} \mathrm{C}\right.$ ) and at low $\mathrm{CT}$ values consistent with those expected for a groundwater site for which there is short distribution system contact time before the water reaches the first consumer; (2) to identify any synergistic effect that may occur when UV and monochloramine are applied sequentially; (3) to detect any significant differences in the inactivation kinetics of adenovirus types 2, 5, and 41 when exposed to UV light.

\section{METHODS}

\section{Propagation, purification and assay of adenovirus}

Ad 5, Ad 2 and Ad 41 (prototype strain Tak) were propagated and assayed in HEK 293 cells (a continuous line of human embryonic kidney cells transformed with Ad5 DNA) 
(Graham et al. 1977). Additional Ad 41 was propagated in PLC/PRF/5 (hepatoma) cells (Alexander et. al. 1976). 293 cells were maintained in minimal essential medium (MEM) supplemented with $10 \%$ fetal bovine serum (FBS). PLC/PRF/5 cells were maintained in MEM supplemented with 10\% FBS, $0.1 \mathrm{mM}$ non-essential amino acids, $1.0 \mathrm{mM}$ sodium pyruvate and $2 \mathrm{mM}$ L-glutamine. All cells were grown to confluence in $75 \mathrm{~cm}^{2}$ flasks at 37 ${ }^{\circ} \mathrm{C}$ and sub-cultured using a trypsin-EDTA solution.

To begin propagation of Ad 2 and Ad 5, culture fluid was removed and $1 \mathrm{~mL}$ of virus inoculum (titre $\sim 10^{8} \mathrm{IU} / \mathrm{mL}$ ) was added to each $75 \mathrm{~cm}^{2}$ flask. After adsorption at $37{ }^{\circ} \mathrm{C}$ for one hour, with rocking at 15-minute intervals to prevent drying of the cells, the inoculum was removed and replaced with fresh culture medium (MEM plus 10\% FBS) and flasks were incubated at $37^{\circ} \mathrm{C}$ until cytopathic effect (CPE) was complete. Under these conditions, most of the cells were infected at the outset and CPE was complete after two cycles of virus replication. In the case of $\mathrm{Ad} \mathrm{41,} \mathrm{the} \mathrm{adsorption} \mathrm{period} \mathrm{was} \mathrm{extended} \mathrm{to} \mathrm{two} \mathrm{hours} \mathrm{at} 37^{\circ} \mathrm{C}$. The titre of the virus inoculum $\left(\sim 10^{5} \mathrm{IU} / \mathrm{mL}\right)$ was sufficient to infect less than $5 \%$ of the cells at the outset and multiple cycles of virus replication were required before CPE was complete. If the cell layer became densely packed before CPE was widespread, the cells were sub-cultured in a 1:2 ratio to promote cycling of the cells and facilitate spread of the virus within the culture. When CPE was complete, cells were dislodged with a sharp slap of the flask (not by scraping) and collected by centrifugation at $300 \mathrm{x} g$ for 10 minutes. The supernatant was discarded and cell pellets were washed with phosphate buffered saline (PBS) (Oxoid) and re-suspended in a minimal volume of serum-free medium before storage at -20 ${ }^{\circ} \mathrm{C}$ until further processing. The use of serum-free medium was important as the bovine serum albumin (BSA) in the FBS used to supplement the media can adhere to virions and 
affect their sensitivity to treatment. The potential for albumin interference is also the reason that the supernatant was discarded following the centrifugation step described above.

To begin purification, cells were subjected to 5 freeze-thaw cycles to release intracellular virus and the lysate was clarified by centrifugation at $300 \mathrm{x} \mathrm{g}$. The pellet of cell debris was re-suspended in $1 \mathrm{~mL}$ of serum-free medium then treated with Vertrel XF (Dupont Chemicals), as described by Mendez et al. (2000) to extract virus trapped within the pellet. The Vertrel extract was then pooled with the clarified cell lysate for virus purification by two rounds of cesium chloride $(\mathrm{CsCl})$ density gradient centrifugation. For the first gradient, the pooled lysate was underlain with a layer of $\mathrm{CsCl}(1.2 \mathrm{~g} / \mathrm{mL}$ in $50 \mathrm{mM}$ Tris- $\mathrm{HCl}$, $\mathrm{pH} 8.1)$ that in turn was underlain with $\mathrm{CsCl}$ of higher density $(1.4 \mathrm{~g} / \mathrm{mL}$ in $50 \mathrm{mM}$ Tris- $\mathrm{HCl}$, $\mathrm{pH}$ 8.1). Following centrifugation at $120,000 \mathrm{x} g$ for one hour, the virus band $(\rho=1.34)$ was collected from the interface between the two $\mathrm{CsCl}$ layers, diluted with $50 \mathrm{mM}$ Tris- $\mathrm{HCl}$, then underlain with $\mathrm{CsCl}(1.4 \mathrm{~g} / \mathrm{mL}$ in $50 \mathrm{mM}$ Tris-HCl, $\mathrm{pH} 8.1)$ and centrifuged at $120,000 \mathrm{x} g$ for 20 hours. The virus band $(\rho=1.34)$ was recovered and dialysed against buffer $(50 \mathrm{mM}$ Tris- $\mathrm{HCl} \mathrm{pH} 7.8,150 \mathrm{mM} \mathrm{NaCl}, 10 \mathrm{mM} \mathrm{MgCl} 2,10 \%$ glycerol). This pure viral stock was stored at $-80{ }^{\circ} \mathrm{C}$ until use in experiments.

Immediately prior to all experiments, the Tris-containing dialysis buffer, in which the virus was stored, was exchanged for $5 \mathrm{mM}$ borate buffer ( $\mathrm{pH} 8.5$ for $\mathrm{Ad} 5$ and $\mathrm{Ad} 41, \mathrm{pH} 8.0$ for Ad 2) by dialysis of up to $1 \mathrm{~mL}$ of purified virus against $500 \mathrm{~mL}$ of cold borate buffer for 2.5 hours with 3 changes of buffer. It was important to remove Tris (Tris(hydroxymethyl)aminomethane) buffer prior to chlorine treatment because of the high chlorine demand it exerts, however for consistency, this dialysis step was performed to prepare the virus used in all experiments. The $5 \mathrm{mM}$ borate buffer was prepared by 
dissolving $0.309 \mathrm{~g} / \mathrm{L}$ boric acid (EM Science) and $0.04 \mathrm{~g} / \mathrm{L}$ sodium hydroxide (Aldrich) in chlorine demand free Milli-Q water (Millipore).

Infectivity was assayed by endpoint dilution using 293 cells in 60-well (Terasaki) plates as described previously (Brown 1985). Briefly, ten-fold dilutions of virus were prepared and $5 \mu \mathrm{L}$ volumes placed in each well, with 9 wells used for each dilution. Cells were added (1000 per well in a $5 \mu \mathrm{L}$ volume) and plates were incubated in a humidified container, at $37^{\circ} \mathrm{C}$ with $5 \% \mathrm{CO}_{2}$. CPE was scored at 10-12 days post infection (p.i.).

Given the fastidious growth characteristics of Ad 41 in cell culture, CPE could be difficult to score at the limiting dilution. Therefore, cells were first scored for CPE then processed for detection of newly made viral protein by fluorescent antibody. Cells at the limiting dilution (lowest dilution with wells showing no CPE) and the two higher dilutions were fixed in $4 \%$ paraformaldehyde for 15 minutes then washed twice with PBS (phosphate buffered saline), permeabilized with PBS-0.1\% Triton X-100 (PBT) for 15 minutes, then blocked with $5 \%$ bovine serum albumin (BSA-PBT) for 45 minutes. Cells were then incubated for 45 minutes at $37^{\circ} \mathrm{C}$ with the primary antibody, 2HX-2 (American Type Culture Collection) in 5\% BSA-PBT, which binds to hexon trimers (Cepko et al. 1983). The cells were rinsed three times with PBS and then incubated with the secondary antibody, FITC-conjugated anti-mouse (Sigma) for 45 minutes at $37^{\circ} \mathrm{C}$. Two more washes were performed and PBS was added before examining cells using an inverted fluorescence microscope. As progeny hexon trimers are formed only in adenovirus-infected cells, cells that emit fluorescence must be infected and can be scored as such. Whether cells were scored for CPE or for presence of newly made viral protein, titres were calculated according to the statistical method of Reed and Muench (1938). 


\section{Chlorine and monochloramine preparation and measurement}

A $100 \mathrm{mg} / \mathrm{L}$ working chlorine stock solution was prepared immediately prior to all chlorine experiments by diluting a $4 \%$ sodium hypochlorite solution (Aldrich) in the same demand free $5 \mathrm{mM}$ borate buffer used to suspend virus stocks for all experiments. Monochloramine was prepared directly in reactors by combining equal volumes of $500 \mathrm{mg} / \mathrm{L}$ ammonium chloride and $400 \mathrm{mg} / \mathrm{L}$ sodium hypochlorite stock solutions at a chlorine-toammonia (as nitrogen) ratio of $4: 1$ by mass. Both stock solutions were prepared in advance in $\mathrm{pH} 9.4,0.1 \mathrm{M}$ carbonate buffer $\left(1.95 \mathrm{~g} / \mathrm{L} \mathrm{Na}_{2} \mathrm{CO}_{3}\right.$ and $\left.6.86 \mathrm{~g} / \mathrm{L} \mathrm{NaHCO}_{3}\right)$.

Chlorine and monochloramine residuals were measured colorimetrically according to the DPD Method (APHA, 1998) using an HP8452A diode-array spectrophotometer (Hewlett Packard).

\section{Chlorine and monochloramine experiments}

All flasks and glass vials used in experiments were made chlorine demand free by soaking overnight in a $100 \mathrm{mg} / \mathrm{L}$ chlorine solution. The chlorine solution was removed by rinsing the flasks and vials three times each in chlorine demand-free Milli-Q ${ }^{\circledR}$ water (Millipore). Experiments with Ad 5 and Ad 41 were conducted at $5{ }^{\circ} \mathrm{C}$ in sterile, demand free Teflon $^{\circledR}$ flasks with Teflon ${ }^{\circledR}$ stir bars containing $60 \mathrm{~mL}$ sterile, demand free $5 \mathrm{mM}$ borate buffer at $\mathrm{pH}$ 8.5. Ad 2 experiments were conducted in the same type of reactors in $5 \mathrm{mM}$ borate buffer, but differed in that they were conducted at $25^{\circ} \mathrm{C}$ and $\mathrm{pH} 8.0$ to replicate conditions from a previous study, as explained further below.

Dialysed virus suspensions were added to the flasks with stirring to achieve a starting titre of $10^{8}$ infectious units per millilitre $(\mathrm{IU} / \mathrm{mL})$ for $\mathrm{Ad} 5$ and $\mathrm{Ad} 2$ experiments and $10^{7}$ $\mathrm{IU} / \mathrm{mL}$ for Ad 41 experiments. For the Ad 2 experiments in which UV light was applied 
before monochloramine, $60 \mathrm{~mL}$ of UV-exposed virus was placed in an empty, sterile Teflon ${ }^{\circledR}$ flask prior to the addition of disinfectant. A timer was started with the addition of the disinfectant to begin the experiments. The duration of the chlorine experiments was 3 minutes, with samples collected to measure microbial and disinfectant residual at 30 seconds and 1, 2 and 3 minutes. The duration of the monochloramine experiments was 2 hours, with microbial and disinfectant residual samples collected at 30, 60, 90 and 120 minutes. Microbial samples were collected in $1.2 \mathrm{~mL}$ microcentrifuge tubes containing $10 \mu \mathrm{L}$ of $10 \%$ sodium thiosulphate to quench residual disinfectant, and stored at $4{ }^{\circ} \mathrm{C}$ until enumeration later the same day. Disinfectant residual samples of $3 \mathrm{~mL}$ were collected in $20 \mathrm{~mL}$ chlorine demand free vials containing $150 \mu 1$ buffer and $150 \mu 1$ DPD and analyzed immediately.

The applied chlorine dose in each experiment was $0.1-0.12 \mathrm{mg} / \mathrm{L}$. The buffer and virus inoculum exerted very low chlorine demand. The virus used in this study was fully purified in an effort to remove soluble proteins that exert a chlorine demand. As a result, the disinfectant demand in all chlorine experiments in this study was no higher than $0.04 \mathrm{mg} / \mathrm{L}$ over the course of any experiment, and was usually $0.01-0.02 \mathrm{mg} / \mathrm{L}$.

The applied monochloramine dose ranged from $1-4 \mathrm{mg} / \mathrm{L}$ and the highest monochloramine demand observed in any experiment was $0.3 \mathrm{mg} / \mathrm{L}$.

For each chemical disinfectant residual measurement time point, the $\mathrm{CT}$ value was calculated by multiplying the measured disinfectant concentration by the time interval since the previous disinfectant measurement. This value was then added to the $\mathrm{CT}$ value calculated at the previous time point to give the overall $\mathrm{CT}$ value. 
Control experiments were conducted beforehand to ensure that there was no virus inactivation due to factors other than disinfection and to confirm that neither the buffers nor the reactor flasks exerted any disinfectant demand.

\section{UV light exposures}

A collimated beam apparatus containing two low pressure UV lamps (Suntec environmental, Concord, ON) was used to expose Ad 5, Ad 2 and Ad 41 to UV light. The UV intensity (or 'fluence rate') was measured at $254 \mathrm{~nm}$ using an IL1700 radiometer equipped with an SUD240 sensor (International Light). Sample depth and UV absorbance were also incorporated into calculations of the exposure times required to apply a range of UV doses (expressed in $\mathrm{mJ} / \mathrm{cm}^{2}$ ), as per the methods described in Bolton and Linden (2003). A UV dose range of 0 to $120 \mathrm{~mJ} / \mathrm{cm}^{2}$ was considered, to compare with the adenovirus inactivation results from previous UV studies that used this dose range (e.g. Meng and Gerba 1996). The exposure times for these UV doses ranged from 85 seconds for $20 \mathrm{~mJ} / \mathrm{cm}^{2}$ up to 510 seconds for $120 \mathrm{~mJ} / \mathrm{cm}^{2}$. A $10^{6} \mathrm{IU} / \mathrm{mL}$ suspension of dialyzed virus was prepared in $\mathrm{pH}$ 8.5 buffer ( $\mathrm{pH} 8.0$ for $\mathrm{Ad} 2$ ) and dispensed in $20 \mathrm{~mL}$ aliquots into sterile Petri dishes, each containing a sterile Teflon ${ }^{\circledR}$ coated micro stir bar. Each aliquot was placed on a support plate in the path of the collimated beam of UV light and exposed, with stirring, for the appropriate time to achieve the desired dose. Exposed virus was stored at $4{ }^{\circ} \mathrm{C}$ until enumeration later the same day.

It is important to note that the UV doses (fluences) applied at bench-scale by collimated beam apparatuses are not equivalent to the UV reduction equivalent doses (RED) quoted by regulations. Collimated beam exposures are controlled trials where the UV fluence 
rate distributions and mixing characteristics are well defined. The RED for flowing UV systems, on the other hand, must be established by validation trials (i.e. biodosimetry tests in which the UV system is challenged with an organism of known UV response characteristics) and incorporate safety factors to account for uncertainties in the process (USEPA 2006). That said, bench-scale UV collimated beam exposures can provide estimates of the response of microorganisms to UV light in flowing systems under ideal conditions (i.e. even distribution of UV light and good mixing characteristics throughout the UV reactor).

\section{RESULTS AND DISCUSSION}

\section{UV light exposures}

UV light exposures were conducted to determine the inactivation kinetics of adenovirus. There was a large amount of variability in the UV dose-response of adenovirus reported by other studies (Fig. 2). To determine whether the degree of purity of the virus preparation that is used may impact UV resistance, experiments were conducted with the clarified lysate of infected cells. This preparation contained virus along with soluble proteins and any debris not pelleted by centrifugation at $300 \mathrm{x} g$ (see Methods section). There was no statistically significant difference in inactivation of Ad 5 in clarified cell lysate compared with that of Ad 5 fully purified by cesium chloride gradient centrifugation and suspended in borate buffer, based on a t-test at the $95 \%$ confidence level (Fig. 3). Despite this observation, the virus used in this study was fully purified in an effort to remove soluble proteins that exert a chlorine demand, as described above. For consistency, and to allow accurate comparisons to be made between the effects of different disinfectants, fully purified virus was used in all experiments. 
A review of the literature concerning adenovirus UV inactivation indicates that there are no standard methods for virus propagation or enumeration (such as exist for MS2 coliphage, for example). Table 1 summarizes the methods used in selected studies and Figure 2 shows the differences in adenovirus inactivation data reported among those studies. The data from the present study is also included in Figure 2. It cannot be determined which, if any, of these differences in methodology may be responsible for the observed differences in the inactivation data. One advantage of the present study is that different adenovirus serotypes were compared at the same time, under the same experimental conditions. Specifically, two species C adenoviruses (Ad 2 and Ad 5), which are found in stool specimens (Brandt et al. 1985, Brown 1990), and a species F adenovirus (Ad 41), which is spread by the fecal-oral route and known to cause disease, were compared using the same conditions for purification and assay.

Due to the limited spread of Ad 41 in a cell culture, the foci of infected cells are often small and can be difficult to distinguish against a background of healthy cells. In contrast, Ad 2 and Ad 5 spread efficiently in cell culture and give rise to larger foci of infected cells which are clearly distinguished from the surrounding cells. The scatter in Ad 41 data due to this effect was reduced in subsequent experiments by using an enumeration technique based on immuno-fluorescent staining of cells with a specific antibody, to visualize the presence of newly synthesized viral capsid protein (hexon). Since these proteins are formed only in infected cells, fluorescence emitted from a micro-plate well indicates adenovirus infection of the cells it contains, allowing it to be enumerated.

This study confirms that collimated beam UV doses of $40 \mathrm{~mJ} / \mathrm{cm}^{2}$ only achieve approximately 1-log of adenovirus inactivation. Although a statistically similar level of 
inactivation of Ad 2, Ad 5 and Ad 41 can be achieved by this UV dose, Ad 41 was found to be more resistant than Ad 2 or Ad 5 at higher UV doses (i.e. $>70 \mathrm{~mJ} / \mathrm{cm}^{2}$ ) to a statistically significant degree ( $95 \%$ confidence) (Fig. 4). While $120 \mathrm{~mJ} / \mathrm{cm}^{2}$ will provide 3-log inactivation of Ad 5 and Ad 2, only 2-log inactivation of Ad 41 is achieved at this UV dose. These findings conflict with the results of Gerba et al. (2002) in which Ad 2 was more resistant than Ad 40 and Ad 41.

One explanation for the observed differences in UV sensitivity among the adenovirus types in this study may be structural differences between respiratory and enteric adenoviruses (Ad 40 and Ad 41), specifically those characteristics that allow the enterics to survive the harsh acidic conditions of the human gastrointestinal tract (Favier et al. 2004). The UV resistance of adenoviruses in general, relative to other enteric viruses, has been proposed to be due to the ability of infected host cells to repair UV-induced damage to the doublestranded DNA genome of the virus (Day et al. 1999, Arnold and Rainbow 1996). This is not possible for single-stranded RNA viruses such as hepatitis A or calicivirus. It is yet to be determined whether the cells used to enumerate adenoviruses in vitro or the cells of the gut that adenoviruses actually infect in vivo possess these repair enzymes.

The UV inactivation kinetics of Ad 5 and Ad 2 observed in this study (Fig. 2) are consistent with those reported for Ad 2 by others (Gerba et al. 2002). Ad 5 and Ad 2 demonstrate statistically similar levels of inactivation (at the $95 \%$ confidence level), which is to be expected considering that these two types of adenovirus are very closely related (van Regenmortel et al. 2000). Further, the UV inactivation kinetics of Ad 41 observed in this study (Fig. 2) were similar to those reported in two previous studies with the other type of fastidious enteric adenovirus, Ad 40 (Thurston-Enriquez et al. 2003, Jacangelo et al. 2002). 
UV inactivation data for all replicate experiments with Ad 5, Ad 2 and Ad 41 are shown in Figure 4, to illustrate the reproducibility of the results. Inactivation data from replicate trials were statistically similar ( $95 \%$ confidence) to other replicates for the same adenovirus type.

The linearity of the UV inactivation curves in Figure $4\left(\mathrm{R}^{2}>0.93\right.$ for all three types of adenovirus) indicates a lack of clumping or aggregation of the virus in the buffer in which it was suspended during experiments (Grant 1995, Thurman and Gerba 1988). In order to obtain consistent and reproducible results, it was important to ensure that UV light was applied to a disperse virus suspension, as outer particles in an aggregate may shield or shadow inner particles. Transmission electron microscopy (TEM) was used to check the level of dispersion of both Ad 5 and Ad 41 (Fig. 5) prior to the start of experiments to ensure that neither the viral propagation methods nor dialysis into $\mathrm{pH} 8.5$ buffer would induce aggregation.

\section{Chlorine and monochloramine}

It was not the intent of this study to define precise adenovirus inactivation kinetics in the presence of chlorine and monochloramine. To do so would have required far more data due to the inherent variability of the methods used, despite our careful efforts to maintain control (e.g. Fig. 6). A thorough investigation of the kinetics would also have required the exploration of a range of temperature and $\mathrm{pH}$. Instead, the main objective of the study was to provide guidance to regulators who must assess whether a UV disinfection system treating water in need of 4-log (adeno)virus inactivation must be preceded or followed by some minimum chlorine contact time, or whether the time during distribution from the treatment 
plant to an adjacent consumer can be considered sufficient. The ability of monochloramine to supplement UV for adenovirus control was also assessed.

The inactivation of Ad 5 and Ad 41 as a function of chlorine CT under near worstcase conditions ( $\mathrm{pH} 8.5$ and $5^{\circ} \mathrm{C}$ ), focusing on low CT values, is shown in Figure 6. The data indicate that a CT of approximately $0.14 \mathrm{mg} \cdot \mathrm{min} / \mathrm{L}$ provided 3-log inactivation of both Ad 5 and Ad 41. A CT of approximately $0.22 \mathrm{mg} \cdot \mathrm{min} / \mathrm{L}$ provided 4-log inactivation. This is close to the $\mathrm{CT}$ of $0.24 \mathrm{mg} \cdot \mathrm{min} / \mathrm{L}$ that Thurston-Enriquez et al. (2003) reported under similar $\mathrm{pH}$ and temperature conditions.

It should be noted that even though CT requirements assigned by regulatory agencies would be augmented by safety factors (e.g. a safety factor of 3.0, USEPA Surface Water Treatment Rule), these results still suggest that the chlorine contact time provided by a distribution pipe would likely be sufficient following UV disinfection to meet 4-log (adeno)virus inactivation (i.e. no separate chlorine contact tank needed for virus control). At lower $\mathrm{pH}$ or warmer temperatures, the rate of inactivation will presumably be even faster. However it other water matrices (i.e. those with higher chlorine demand or turbidity) may require longer chlorine $\mathrm{CT}$ values for adenovirus inactivation than the ones quoted here.

In contrast, monochloramine was not nearly as effective at inactivating adenovirus under the conditions of these experiments, even at much higher $\mathrm{CT}$ values than in the chlorine experiments. For example, a CT of $300 \mathrm{mg} \cdot \mathrm{min} / \mathrm{L}$ yielded only $2.5-\log$ inactivation of Ad 5 and Ad 41 (Fig. 7). This suggests that UV light at traditional doses in the order of 40 $\mathrm{mJ} / \mathrm{cm}^{2}$ followed by preformed monochloramine or possibly monochloramine formed by the application of ammonia prior to chlorine (such that little free chlorine is ever present) may not be a viable adenovirus treatment strategy. 


\section{Sequential UV and monochloramine}

For the Ad 5 and Ad 41 experiments reported above, UV light, chlorine, and monochloramine were applied separately rather than sequentially, since previous studies have shown that they have an additive, rather than synergistic virucidal effect (Shin et al. 2002, Coronell et al. 2003). Ballester and Malley (2004) reported the effect on Ad 2 when UV and monochloramine were applied sequentially but did not address the possibility of synergistic effects - i.e. the potential for UV-irradiated Ad 2 to be more susceptible to monochloramine than non-irradiated Ad 2. In an effort to investigate this possibility, the current study included experiments with Ad 2 to determine if prior exposure to UV light would result in greater susceptibility to monochloramine.

A UV dose-response curve was first constructed for Ad 2 (Fig. 4). Monochloramine experiments were then conducted in parallel at $25{ }^{\circ} \mathrm{C}$ and $\mathrm{pH} 8.0$, to replicate conditions used in the Ballester and Malley (2004) study, in $5 \mathrm{mM}$ borate buffer. A CT of $150 \mathrm{mg} \cdot \mathrm{min} / \mathrm{L}$ provided 5-log reduction of Ad 2 (data points labelled " $\mathrm{NH}_{2} \mathrm{Cl}$ only" in Fig. 8). The experiments were then repeated under the same conditions, at the same CT values, with Ad 2 that had been exposed to $45 \mathrm{~mJ} / \mathrm{cm}^{2}$ of UV less than 30 minutes earlier (Fig. 8). There was no statistically significantly difference (at the $95 \%$ confidence level) in the inactivation of the UV-exposed virus by monochloramine versus the inactivation of non-UV-exposed virus by monochloramine (Fig. 8). Therefore there is no evidence of a synergistic effect of using UV followed by monochloramine for the inactivation of Ad 2. A synergistic effect would not necessarily be expected, since the inactivation mechanisms of UV light (photochemical reaction with DNA) and monochloramine (e.g. oxidation) are different and may therefore have independent effects. 
No sequential UV and free chlorine experiments were conducted since previous experiments in this study showed that chlorine is extremely effective at inactivating $\operatorname{Ad} 5$ and 41 even at very low CT values (Fig. 6), and therefore any additional synergistic effects of UV followed by chlorine was not deemed to be worth investigating.

\section{Potential impacts of viral aggregation or particle-association}

This study and others have used dispersed virus suspended in pure laboratory-grade waters or ground water with very low turbidity (Thurston-Enriquez et al. 2003, Jacangelo et al. 2002, Gerba et al. 2002, Meng and Gerba 1996). However, it is more likely that viruses will exist in an aggregated or particle-associated state in surface or ground waters (Young and Sharp 1977, Hejkal et al. 1979). Viral aggregates are expected to be more resistant to disinfection than dispersed viruses because of the protective effect afforded inner viral particles by those that surround them (Grant 1995, Thurman and Gerba 1988). It is also possible that the close association of viral particles may allow for cooperative reactivation when components of an aggregate damaged by disinfection infect a single cell. This phenomenon, termed "multiplicity reactivation" involves recombination among two or more damaged genomes to generate a genome that is competent for productive infection (i.e. production of infectious progeny virus) (Grant 1995 and Ramig 1992). It has generally been reported to occur with UV-irradiated viruses (Sharp 1968) and is consistent with UV-

mediated damage to viral DNA rather than damage to the capsid preventing binding and entry of the virus (Rainbow and Mak 1973).

The results of this study, and others similarly using dispersed viruses, should therefore be interpreted with caution. Ideally, future research would explore whether such 
factors that could affect inactivation kinetics in the field are significant and warrant changes to our laboratory techniques.

\section{SUMMARY}

The motivation for this study was to determine whether UV disinfection followed by chlorine or monochloramine for a very short contact time (e.g. a minute) could satisfy regulatory requirements for 4-log virus inactivation. Such a scenario is relatively common, for example, in instances where a well pumping groundwater under the influence of surface water is located adjacent to a consumer.

Adenovirus type 41 (Ad 41) was found to be more resistant to UV light than Ad 2 or Ad 5 for low pressure UV collimated beam doses $>70 \mathrm{~mJ} / \mathrm{cm}^{2}$ (with $95 \%$ confidence). Ad 41 inactivation kinetics were similar to those for Ad 40 reported by earlier studies.

Two types of adenovirus, Ad 5 and Ad 41, were exposed to chlorine and monochloramine under presumptive near-worst-case conditions $\left(\mathrm{pH} 8.5,5^{\circ} \mathrm{C}\right)$. Chlorine quickly inactivated both types of adenovirus, with 3-log inactivation achieved for a CT of approximately $0.14 \mathrm{mg} \cdot \mathrm{min} / \mathrm{L}$, and 4-log inactivation for a CT of approximately 0.22 $\mathrm{mg} \cdot \mathrm{min} / \mathrm{L}$. To put this into context, it is argued that when applying a typical chlorine dose of $1 \mathrm{mg} / \mathrm{L}$, there is no need for contact time beyond that which will exist within the distribution system between the plant and the first consumer to ensure that 4-log inactivation of adenovirus is achieved.

In contrast to chlorine, monochloramine proved to be only weakly effective against Ad 5 and 41 with at most a 2.7-log inactivation observed at the highest CT applied of 340 
$\mathrm{mg} \cdot \mathrm{min} / \mathrm{L}$. There was no observed benefit to applying UV prior to monochloramine in terms of enhancing the effectiveness of monochloramine.

\section{ACKNOWLEDGEMENTS}

The authors would like to thank the Ontario Ministry of the Environment for funding support, as well as Carmen Yea for preparation and enumeration of virus and Steven Doyle for his assistance with electron microscopy.

\section{REFERENCES}

Alexander, J.J., Bey, E.M., Geddes, E.W., Lecatsas, G. (1976). "Establishment of a continuously growing cell line from primary carcinoma of the liver." S. Afr. Med. J., 50(54), 2124-8.

American Public Health Association (APHA). (1998). Standard Methods for the Examination of Water and Wastewater, $20^{\text {th }}$ ed. APHA, Washington, DC.

Arnold, W.R.G. and Rainbow, A.J. (1996). "Host cell reactivation of irradiated adenovirus in UV-sensitive Chinese hamster ovary cell mutants." Mutagenesis., 11(1), 89-94.

Ballester, N.A. and Malley, J.P. (2004). "Sequential disinfection of adenovirus type 2 with UV-chlorine-chloramine.” J. Am. Wat. Works Assoc., 96(10), 97-103. 
Bolton, J.R. and Linden, K.G. (2003). "Standardization of methods for fluence (UV dose) determination in bench-scale UV experiments." J. Environ. Eng.., 129(3), 209-215.

Bolton, J.R., Dussert, B., Bukhari, Z., Hargy, T., Clancy, J. L. (1998). "Inactivation of Cryptosporidium parvum by medium-pressure ultraviolet light in finished drinking water". Proc. AWWA Annual Conference, June 21-25, Dallas, TX.

Brandt, C.D., Kim, H.W., Rodriguez, W.J., Arrobio, J.O., Jeffries, B.C., Stallings, E.P., Lewis, C., Miles, A.J., Gardner, M.K., Parrott, R.H. (1985). “Adenoviruses and pediatric gastroenteritis." J. Infect. Dis., 151(3), 437-443.

Brown, M. (1985). "Selection of nonfastidious adenovirus species in 293 cells inoculated with stool specimens containing adenovirus 40.” J. Clin. Microbiol., 22(2), 205-209.

Brown, M., H.L. Wilson-Friesen, Doane, F. (1992). “A block in release of progeny virus and a high particle-to-infectious unit ratio contribute to poor growth of enteric adenovirus types 40 and 41 in cell culture." J. Virol., 66(5), 3198-3205.

Bukhari, Z., Hargy, T.M.. Bolton, J.R., Dussert, B., Clancy, J.L. (1999). “Medium-pressure UV for oocyst inactivation.” Journal AWWA., 91(3), 86-94. 
Cepko, C.L., Whetstone, C.A., Sharp, P.A. (1983). “Adenovirus hexon monoclonal antibody that is group specific and potentially useful as a diagnostic reagent." J. Clin. Microbiol., 17(2), 360-364.

Chapron, C.D., Ballester, N.A., Fontaine, J.H., Frades, C.N., Margolin, A.B. (2000). "Detection of astroviruses, enteroviruses, and adenovirus types 40 and 41 in surface waters collected and evaluated by the information collection rule and an integrated cell culturenested PCR procedure.” Appl. Environ. Microbiol., 66(6), 2520-2525.

Coronell, O., Page, M., Marinas, B.J. (2003). "Sequential disinfection strategies with UV, ozone and chlorine for optimum control of viruses, spores, and Cryptosporidium parvum oocysts”. Proc. AWWA WQTC, Nov. 2-6, Philadelphia, PA.

Day, R.S., Rasouli-Nia, A., Meservy, J., Lari, S., Dobler, K., Tsunoda, S., Miyakoshi, J., Takebe, H., Murray, D. (1999). "Decreased host-cell reactivation of UV-irradiated adenovirus in human colon tumor cell lines that have normal post-UV survival." Photochem. Photobiol. 70(2), 217-227.

D’Angelo, L.J., Hierholzer, J.C., Keenlyside, R.A., Anderson, L.J., Martone, W.J. (1979). "Pharyngoconjunctival fever caused by adenovirus type 4: Report of a swimming poolrelated outbreak with recovery of virus from pool water.” J. Infect. Dis., 140(1), 42-47. 
DVGW. (1997). German association on gas and water technical standard W 294: UV systems for disinfection in drinking water supplies - requirements and testing. DVGW Standards and Guidelines. Bonn, Germany.

Ellis, C., Wells, A.A., Heyroth, F.F. (1941). "The chemical action of ultraviolet rays", $2^{\text {nd }}$ Ed., Reinhold, New York, NY.

Enriquez, C.E., Hurst, C.J., Gerba, C.P. (1995). "Survival of the enteric adenoviruses 40 and 41 in tap, sea, and waste water." Wat. Res., 29(11), 2548-2553.

Favier, A-L., Schoehn, G., Jaquinod, Hars, C., Chroboczek, J. (2002). "Structural studies of human enteric adenovirus type 41." Virology, 293(1), 75-85.

Favier, A-L., Burmeister, W.P., Chroboczek, J. (2004). "Unique physicochemical properties of human enteric Ad41 responsible its survival and replication in the gastrointestinal tract." Virology, 322(1), 93-104.

Gerba, C.P., Gramos, D.M., Nwachuku, N. (2002). "Comparative inactivation of enteroviruses and adenovirus 2 by UV light." Appl. Environ. Microbiol., 68(10), 5167-5169.

Graham, F.L., Smiley, J., Russell, W.C., Nairn, R. (1977). "Characteristics of a human cell line transformed by DNA from human adenovirus type 5." J. Gen. Virol., 36(1), 59-74. 
Grant, S.B. (1995). “Inactivation kinetics of viral aggregates.” J Env. Eng., 121(4), 31-319.

Harm, W. (1980). Biological effects of ultraviolet radiation. Cambridge University Press, Cambridge, UK.

Hejkal, T.W., Wellings, F.M., LaRock, P.A., Lewis, A.L. (1979). "Survival of poliovirus within organic solids during chlorination.” Appl. Environ. Microbiol., 38(1), 114-118.

Jacangelo, J.G., Patania, N.L., Trussell, R.R., Haas, C.N., Gerba, C. (2002). Inactivation of waterborne emerging pathogens by selected disinfectants, American Water Works Research Foundation (AwwaRF), Denver, CO.

Kukkula, M., Arstila, P., Klossner, M., Maunula, L., Bonsdorff, C.V., Jaatinen, P. (1997). “Waterborne outbreak of viral gastroenteritis." Scand. J. Infect. Dis., 29(4), 415-418.

Lee, S. and Kim, S. (2002). "Detection of infectious enteroviruses and adenoviruses in tap water in urban areas in Korea." Wat. Res., 36(1), 248-256.

Linden, K.G., Shin, G., Faubert, G., Carns, W., Sobsey, M.D. (2002). "Inactivation of Giardia lamblia cysts by low pressure UV radiation.” Envir. Sci. Eng., 36(11), 2519-2522. 
Martone, W.J., Hierholzer, J.C., Keenlyside, R.A., Fraser, D.W., D’Angelo, L.J., Winkler, W.G. (1980). "An outbreak of adenovirus type 3 disease at a private recreation center swimming pool.” Am. J. Epidemiol., 111(2), 229-237.

McMillan, N.S., Martin, S.A., Sobsey, M.D. (1992). “Outbreak of pharyngoconjuctival fever at a summer camp - North Carolina." MMWR, 41, 342-344.

Mendez, I.I., Hermann, L.L., Hazelton, P.R., Coombs, K.M. (2000). “A comparative analysis of Freon substitutes in the purification of reovirus and calicivirus." J. Virol. Methods., 90(1), $59-67$.

Meng, Q.S. and Gerba, C.P. (1996). "Comparative inactivation of enteric adenoviruses, poliovirus and coliphages by ultraviolet irradiation.” Wat. Res., 30(11), 2665-2668.

National Water Research Institute/American Water Works Association Research Foundation (NWRI-AWWA). (2003). Ultraviolet disinfection guidelines for drinking water and water reuse (updated $2^{\text {nd }}$ edition), National Water Research Institute, Fountain Valley, CA.

Ontario Ministry of Environment (MOE) (2003). Procedure for disinfection of drinking water in Ontario. 
ONORM. (2001). Plants for the disinfection of water using ultraviolet radiation: requirements and testing, low pressure mercury lamp plants, M 5873-1. Osterreichisches Normungsinstitut, Vienna, Austria.

Pieniazek, N.J., Slemenda, S.B., Pieniazek, D., Velarde, J., Luftig, R.B. (1990). "Human enteric type 41 (Tak) contains a second fiber protein gene.” Nucleic Acids Res., 18(7), 1901.

Rainbow, A.J. and Mak, S. (1973). "DNA damage and biological function of human adenovirus after U.V.-irradiation.” Int. J. Radiat.Biol., 24(1), 59-72.

Ramig, R.F. (1992). Principles of animal virus genetics in Fundamental virology, $2^{\text {nd }}$ Ed., B.N. Fields and D.M. Knipe, eds., Raven Press, New York, NY, 109.

Reed, L.J. and Muench, H. (1938). "A simple method of estimating fifty per cent endpoints.” Am J Hyg., 27, 493-497.

Sharp, D.G. (1968). "Multiplicity reactivation of animal viruses." Prog. Med. Virol., 10(1), 64-109.

Shin, G., Ishida, G., Linden, K.G., Sobsey, M.G. (2002). "Sequential disinfection with UV irradiation and chlorine species on several important waterborne pathogens." Proc., American Water Works Association Water Quality and Technology Conference, Nov. 10-14, Seattle, WA. 
Shin, G., Linden, K.G., Sobsey, M.D. (2001). "Low pressure inactivation of pathogenic enteric viruses and bacteriophages." Proc., American Water Works Association Water Quality and Technology Conference, Nov. 11-15, Nashville, TN.

Thompson, S.S., Jackson, J.L. Suva-Castillo, M., Yanko, W.A., Jack, Z.E., Kuo, J., Chen, C., Williams, F.P., Schnurr, D.P. (2003). "Detection of infectious human adenoviruses in tertiary-treated and ultraviolet-disinfected wastewater.” Wat. Env. Res. 75(2), 163-170.

Thurman, R.B. and Gerba, C.P. (1988). "Molecular mechanisms of viral inactivation by water disinfectants." Adv. Appl. Microbiol. 33, 75-105.

Thurston-Enriquez, J.A., Haas, C.N., Jacangelo, J., Riley, K., Gerba, C.P. (2003). "Inactivation of feline calicivirus and adenovirus type 40 by UV radiation." Appl. Environ. Microbiol. 69(1), 577-582.

Thurston-Enriquez, J.A., Haas, C.N., Jacangelo, J., Gerba, C.P. (2003). “Chlorine inactivation of adenovirus type 40 and feline calicivirus". Appl. Environ. Microbiol. 69(7), 3979-3985.

Uhnoo, I., Wadell, G., Svensson, L., Johansson, M.E. (1984). "Importance of enteric adenoviruses 40 and 41 in acute gastroenteritis in infants and young children." J. Clin. Microbiol. 20(3), 365-372. 
United States Environmental Protection Agency (USEPA) (2006). Ultraviolet disinfection guidance manual. Long Term 2 Enhanced Surface Water Treatment Rule, Office of Ground Water and Drinking Water, Washington, D.C.

United States Environmental Protection Agency (USEPA) (1999). EPA Guidance Manual Disinfection Profiling and Benchmarking. Prepared by SAIC for the USEPA, Office of Ground Water and Drinking Water, Washington, D.C.

United States Environmental Protection Agency (USEPA) (1989). "National Primary Drinking Water Regulations; Giardia lamblia, viruses, and legionella, maximum contaminant levels, and turbidity and heterotrophic bacteria (Surface Water Treatment Rule), Final Rule". 43 FR 27486. June 29.

Van Heerden, J., Ehlers, M.M., Van Zyl, W.B., Grabow, W.O.K. (2003). "Incidence of adenoviruses in raw and treated water." Wat. Res. 37(15), 3704-3708.

van Regenmortel, M. H. V., Fauquet, C. M., Bishop, D. H. L., Carstens, E. B., Estes, M. K., Lemon, S. M., Maniloff, J., Mayo, M. A., McGeoch, D. J., Pringle, C. R., Wickner, R. B. (editors) (2000). Virus Taxonomy. Seventh Report of the International Committee on Taxonomy of Viruses. San Diego, Academic Press. 
Young, D.C. and Sharp, D.G. (1977). "Poliovirus aggregates and their survival in water." Appl. Environ. Microbiol. 33(1), 168-177. 
Table 1: Virus production and enumeration methods used in previous adenovirus inactivation studies

\begin{tabular}{|c|c|c|c|c|}
\hline Reference & $\begin{array}{l}\text { Host Cell for } \\
\text { Propagation } \\
\text { and } \\
\text { Enumeration }\end{array}$ & $\begin{array}{l}\text { Number of } \\
\text { freeze-thaw } \\
\text { cycles to } \\
\text { release } \\
\text { intracellular } \\
\text { virus }\end{array}$ & $\begin{array}{l}\text { Purification and } \\
\text { Concentration } \\
\text { Procedure }\end{array}$ & $\begin{array}{l}\text { Number of } \\
\text { wells/dilution } \\
\text { for enumeration }\end{array}$ \\
\hline $\begin{array}{l}\text { This study } \\
\text { (Ad 5, } \\
\text { Ad 41,Ad 2) }\end{array}$ & $\begin{array}{c}293 \\
\text { (and also } \\
\text { PLC/PRF/5 for } \\
\text { Ad } 41 \\
\text { propagation) }\end{array}$ & 5 & $\begin{array}{l}\text { - cell lysate and } \\
\text { extracted cell pellet } \\
\text { treated } \\
\text { - cesium chloride } \\
\text { gradient } \\
\text { - Dialysis to suspend } \\
\text { in Tris buffer }\end{array}$ & 9 \\
\hline $\begin{array}{l}\text { Meng and Gerba, } \\
1996 \\
\text { (Ad } 40 \text { and } \\
\text { Ad } 41 \text { ) }\end{array}$ & $\mathrm{PLC} / \mathrm{PRF} / 5$ & 5 & $\begin{array}{l}\text { - only cell lysate } \\
\text { treated } \\
\text { - Freon, 30min. stir } \\
\text { - } 10 \text { min. centrifuge } \\
\text { - Aqueous phase } \\
\text { ultracentrifuged } 3 \\
\text { hours } \\
\text { - Pellet re-suspended }\end{array}$ & 4 \\
\hline $\begin{array}{l}\text { Thurston- } \\
\text { Enriquez et al., } \\
2003 \text { and } \\
\text { Jacangelo et al., } \\
2002 \\
\text { (both Ad 40) }\end{array}$ & $\mathrm{PLC} / \mathrm{PRF} / 5$ & 1 & $\begin{array}{l}\text { - only cell lysate } \\
\text { treated } \\
\text { - PEG, overnight stir } \\
\text { - } 30 \text { min. centrifuge } \\
\text { - Pellet re-suspended } \\
\text { - Chloroform } \\
\text { extraction }\end{array}$ & 4 \\
\hline $\begin{array}{l}\text { Gerba et al., } 2002 \\
\text { (Ad 2) }\end{array}$ & $\mathrm{PLC} / \mathrm{PRF} / 5$ & 1 & $\begin{array}{l}\text { - only cell lysate } \\
\text { treated } \\
\text { - PEG, overnight stir } \\
\text { - } 30 \text { min. centrifuge } \\
\text { - Pellet re-suspended }\end{array}$ & 6 \\
\hline
\end{tabular}

$\overline{\mathrm{PEG}}=$ polyethylene glycol 


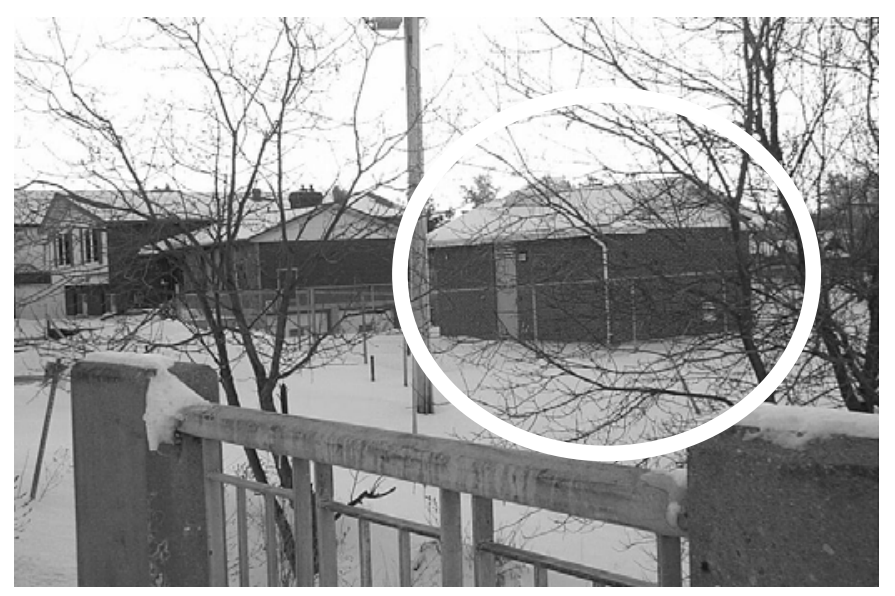

Figure 1: A small groundwater treatment facility (circled), with the houses of the first consumers shown nearby 


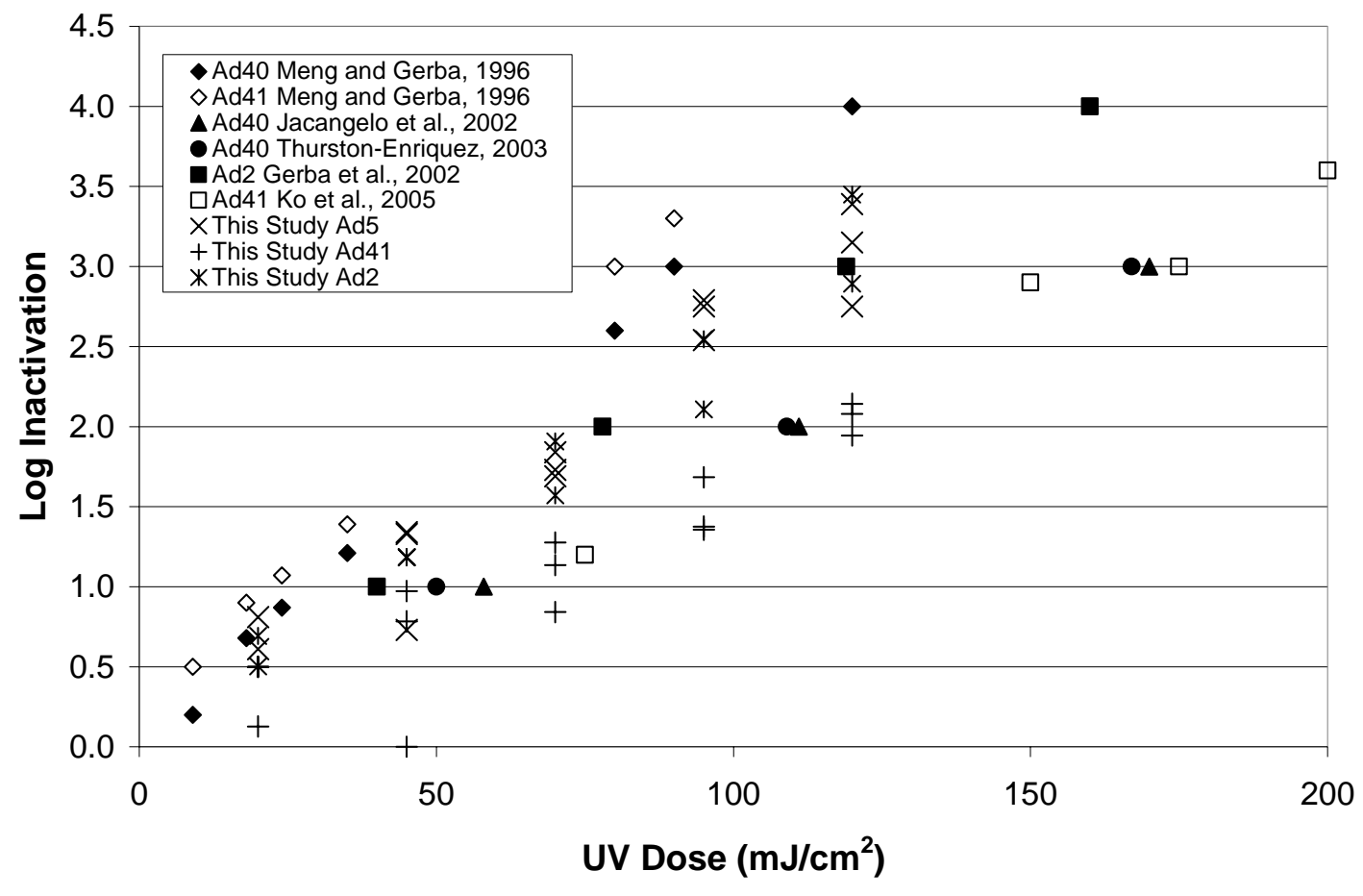

Figure 2: UV inactivation reported in previous studies and in the present study 


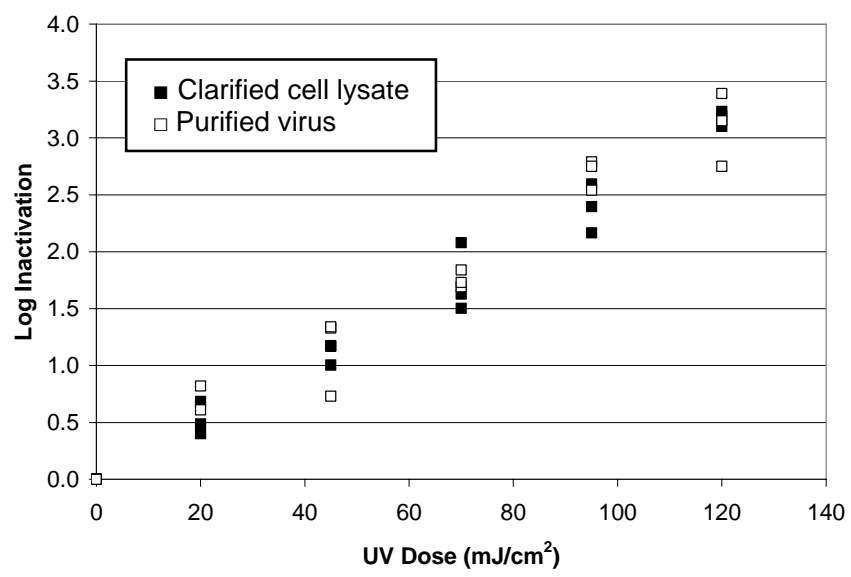

Figure 3: UV inactivation of Ad 5: clarified cell lysate and purified virus 


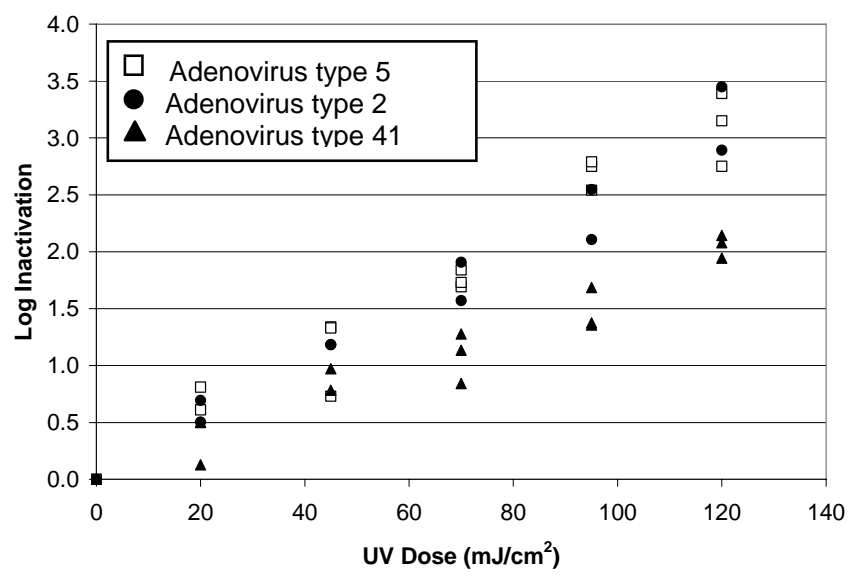

Figure 4: UV inactivation of Ad 5, Ad 2 and Ad 41 
a.

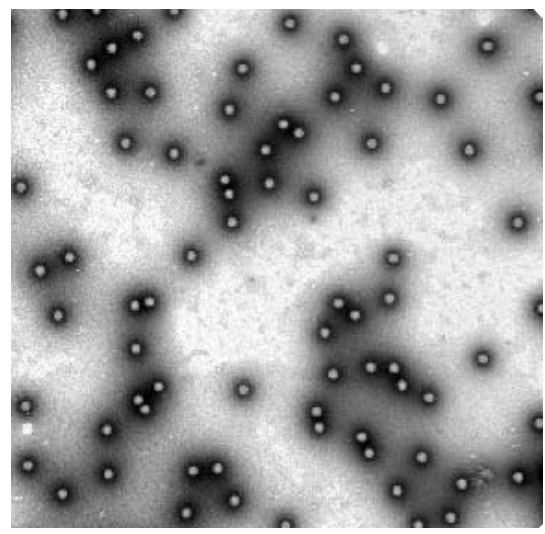

b.

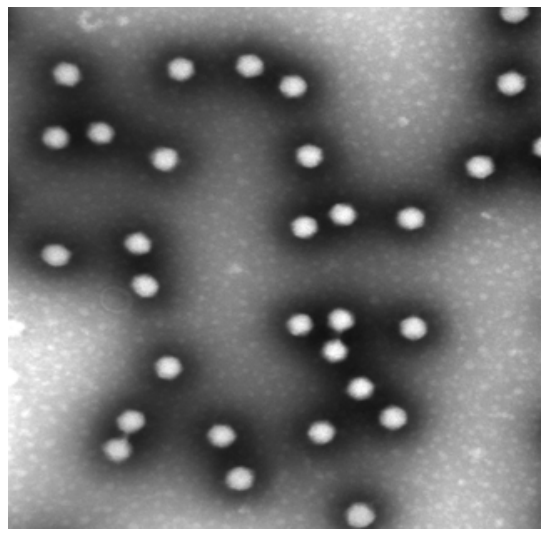

Figure 5: TEM (transmission electron microscopy) images of (a) Ad 5 and (b) Ad 41 in pH 8.5 borate buffer ( 1 viral particle $=75 \mathrm{~nm}$ ) 


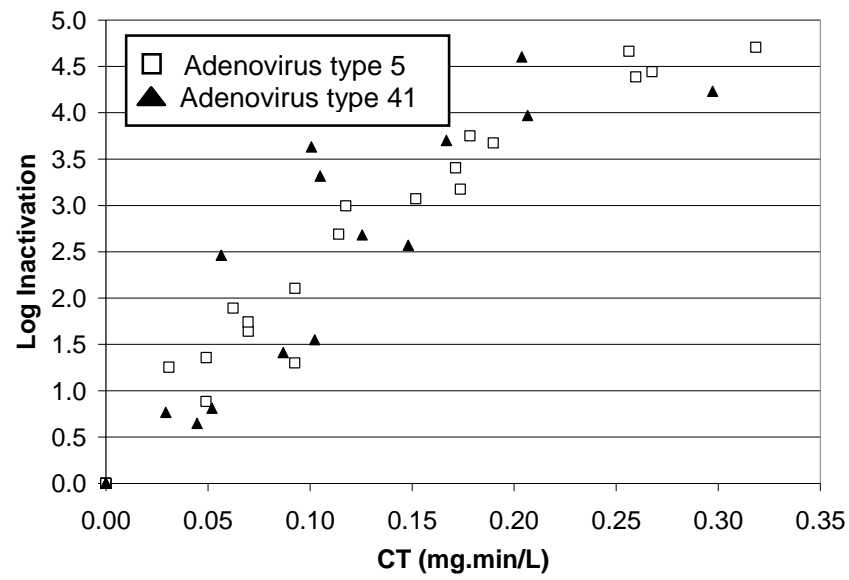

Figure 6: Chlorine inactivation of Ad 5 and Ad 41 at pH 8.5 and $5^{\circ} \mathrm{C}$ 


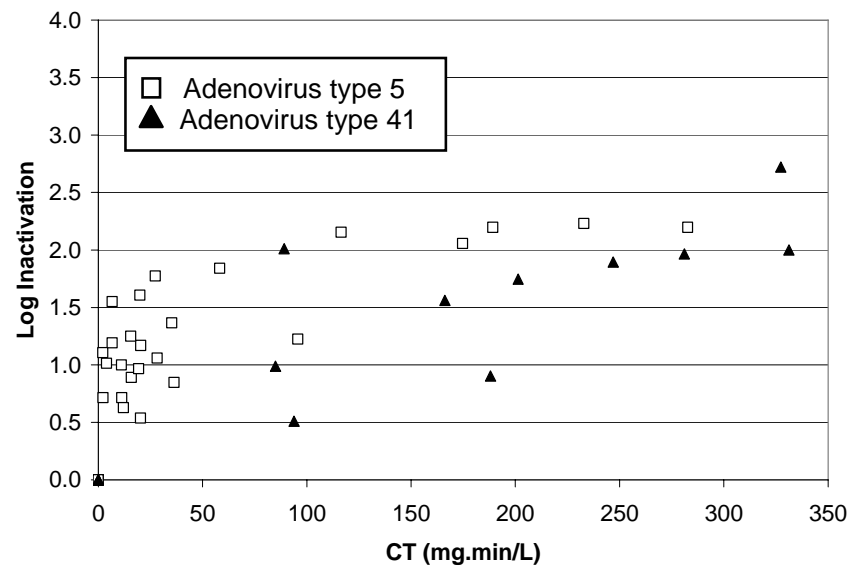

Figure 7: Monochloramine inactivation of Ad 5 and $\mathrm{Ad} 41$ at $\mathrm{pH} 8.5$ and $5^{\circ} \mathrm{C}$ 


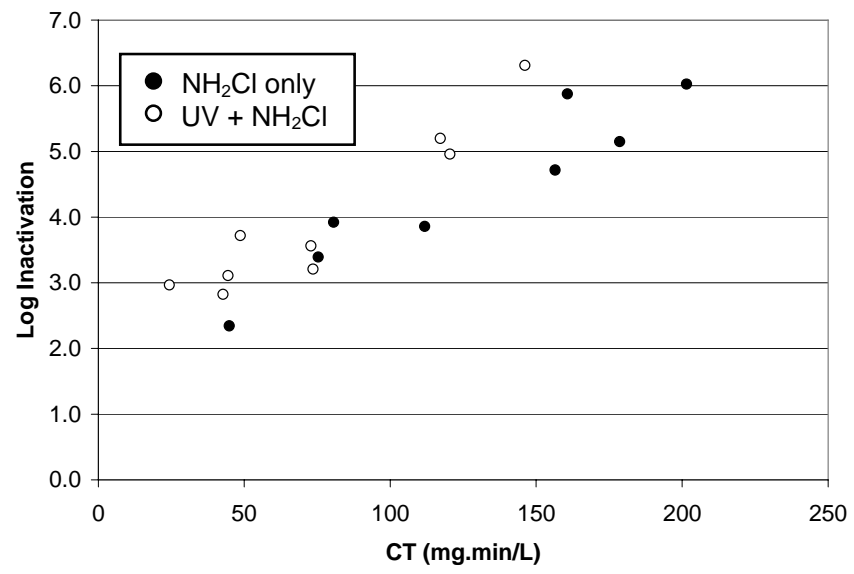

Figure 8: Monochloramine inactivation of Ad 2 with $(\circ)$ and without $(\bullet)$ prior $\mathrm{UV}$ exposure at pH 8.0 and $25^{\circ} \mathrm{C}$ 


\section{List of Figures}

Figure 1: A small groundwater treatment facility

(circled), with the houses of the first

consumers shown nearby.

Figure 2: UV inactivation reported in previous studies and in the present study

Figure 3: UV inactivation of Ad 5: clarified cell

lysate and purified virus

Figure 4: UV inactivation of Ad 5, Ad 2 and Ad 41

Figure 5: TEM (transmission electron microscopy) images of (a) Ad 5 and (b) Ad 41 in pH 8.5 borate buffer $(1$ viral particle $=75 \mathrm{~nm})$

Figure 6: Chlorine inactivation of $\mathrm{Ad} 5$ and

Ad 41 at $\mathrm{pH} 8.5$ and $5^{\circ} \mathrm{C}$

Figure 7: Monochloramine inactivation of Ad 5

and $\mathrm{Ad} 41$ at $\mathrm{pH} 8.5$ and $5^{\circ} \mathrm{C}$

Figure 8: Monochloramine inactivation of $\mathrm{Ad} 2$

with (०) and without $(\bullet)$ prior UV

exposure at $\mathrm{pH} 8.0$ and $25^{\circ} \mathrm{C}$ 